\title{
Penerapan PBL dengan Suplemen Komik Digital terhadap Kemampuan Pemecahan Masalah dan Sikap Peduli Lingkungan
}

\author{
Berliana Okta Aninda a, ${ }^{\star}$, I Gusti Putu Suryadarma b, 2 \\ a Pendidikan Biologi Pascasarjana, Universitas Negeri Yogyakarta, Jl. Colombo No.1, Caturtunggal, Depok, Sleman, 55281, Indonesia \\ b Pendidikan Biologi FMIPA, Universitas Negeri Yogyakarta, J1. Colombo No.1, Caturtunggal, Depok, Sleman, 55281, Indonesia \\ ${ }^{1}$ berliana17@gmail.com*; ${ }^{2}$ samodhaya@yahoo.com \\ *korespondensi penulis
}

\begin{abstract}
ABSTRAK
Penelitian ini bertujuan untuk mengetahui pengaruh penerapan Problem-based Learning (PBL) dengan suplemen komik digital terhadap kemampuan pemecahan masalah dan sikap peduli lingkungan di SMAN 1 Sedayu pada materi pencemaran lingkungan. Penelitian ini merupakan eksperimen semu dengan menggunakan pretest pos-test non-equivalent control group design. Sampel penelitian ditentukan dengan teknik purposive sampling. Kelas X MIA2 dengan penerapan PBL disertai komik digital, kelas X MIA1 dengan penerapan PBL tanpa komik digital, kelas X MIA4 dengan penerapan pembelajaran konvensional disertai komik digital, dan kelas X MIA3 sebagai kelas kontrol. Data kemampuan pemecahan masalah diperoleh dari pretest dan post-test, sedangkan data sikap peduli lingkungan diperoleh dari angket. Instrumen penelitian berupa soal pretest dan post-test sebanyak enam soal, dengan validitas berada pada INFIT MNSQ $\geq 0,77$ sampai $\leq 1,30$. Data penelitian dianalisis menggunakan ANCOVA. Penerapan $P B L$ dengan suplemen komik digital memberikan pengaruh yang terbaik terhadap hasil kemampuan pemecahan masalah dan sikap peduli lingkungan dibandingkan dengan penerapan PBL tanpa komik digital, penerapan pembelajaran secara konvensional ditambah dengan komik digital, dan kelas kontrol.
\end{abstract}

Kata kunci: komik digital, pemecahan masalah, problem based learning, sikap peduli lingkungan

\begin{abstract}
Application of PBL with Digital Comic Supplements on Problem-Solving Abilities and Environmental Awareness. This study aim to determine the effect of Problem-based Learning (PBL) implementation with digital comic supplements on the ability of problem solving and environmental awareness in SMAN 1 Sedayu on environmental pollution subject. This research were a quasi-experiment using pretest post-test non-equivalent control group design. Respondents were determined by purposive sampling technique. Class X MIA2 used the application of PBL with digital comics, class X MIA1 used the application of PBL without digital comics, MIA4 X used the application of conventional learning with digital comic, and class X MIA3 as control class. The data of problem solving ability was obtained from pretest and post-test, while environmental awareness data was obtained from questionnaire. The research instrument were six questions as pretest and post-test, with validity is INFIT MNSQ $\geq 0,77$ until $\leq 1,30$. Research data were analyzed using ANCOVA. The application of PBL with digital comic supplements gives the best effect on the results of problem solving abilities and environmental awareness compared to the application of PBL without digital comics, conventional learning applications with digital comics, and control classes.
\end{abstract}

Keyword: digital comics, problem solving, problem based learning, environmental awareness

Copyright (C) 2017 Universitas Ahmad Dahlan. All Right Reserved

\section{Pendahuluan}

Pendidikan merupakan cara yang dilakukan untuk meningkatkan kualitas bangsa. Kemajuan suatu bangsa dapat diukur dengan kemajuan pendidikannya. Harsanto (2011) mengemukakan suatu sistem pendidikan dikatakan berkualitas jika proses pembelajarannya berlangsung secara menarik dan menantang sehingga peserta didik dapat belajar sebanyak mungkin melalui proses belajar yang berkelanjutan. Proses yang berkualitas menghasilkan pendidikan yang berkualitas. Pendidikan yang berkualitas akan meningkatkan kualitas kehidupan bangsa.

Kurikulum 2013 disiapkan untuk mencetak generasi yang siap dalam menghadapi masa depan (Kemendikbud, 2013). Pembelajaran pada Kurikulum
2013 ditekankan pada pengembangkan keterampilan berpikir kritis, kebebasan dalam berpikir pembangunan kepercayaan diri dalam mengajukan dan menyelesaikan atau mencari pemecahan masalah atau pertanyaan. Melalui hal tersebut diharapkan peserta didik memiliki kompetensi sikap, keterampilan, dan pengetahuan jauh lebih baik.

Pengembangan sikap salah satunya sikap peduli lingkungan relevan dengan kurikulum 2013 yang mengusung adanya keseimbangan antara sikap, keterampilan, dan pengetahuan untuk membangun soft skills dan hard skills. Ranah sikap harus lebih banyak dikenalkan dan diajarkan pada anak, kemudian diikuti dengan ranah keterampilan dan ranah pengetahuan. Ranah sikap yang terdapat pada Kompetensi Inti (KI) 2 adalah sikap peduli lingkungan. 
Pembelajaran di Indonesia pada kenyataannya menunjukkan bahwa peserta didik hanya menghafal konsep dan kurang mampu menggunakan konsep tersebut jika menemui masalah-masalah dalam kehidupan nyata yang berhubungan dengan konsep yang dimiliki. Peserta didik bahkan kurang mampu menentukan dan merumuskan masalah. Walaupun demikian, disadari bahwa ada juga peserta didik yang memiliki kemampuan menghafal yang baik serta mampu memahami materi yang dihafal tersebut namun kenyataan mereka sering kurang mampu dalam menggunakan konsep yang telah dihafal tersebut ke dalam suatu situasi yang baru khususnya yang berkaitan dengan lingkungan sehari-hari (Trianto, 2009).

Perkembangan pendidikan harus diikuti dengan proses pendidikan yang dijalankan sesuai dengan ketentuan yang bersifat mendasar bagi perkembangan ilmu pengetahuan. Salah satu yang menunjang proses pendidikan yang baik yaitu dengan penerapan model pembelajaran yang sesuai dengan materi.

Model pembelajaran yang menjadikan peserta didik sebagai pusat pembelajaran salah satunya adalah penerapan model Problem-based Learning $(P B L)$. Problem-based learning adalah suatu pendekatan pembelajaran dengan membuat konfrontasi kepada pebelajar dengan masalahmasalah praktis atau pembelajaran yang dimulai dengan pemberian masalah dan memiliki konteks dengan dunia nyata (Tan, 2003). Model problembased learning dapat melatih peserta didik untuk memecahkan masalah dengan pengetahuan yang dimilikinya. Proses pembelajaran menggunakan $P B L$ dapat membangun pengetahuan baru yang lebih bermakna bagi peserta didik.

Problem-based learning adalah model pembelajaran yang dirancang dengan mengangkat masalah kehidupan nyata yang terstruktur ,terbuka, dan ambigu. Masalah yang disediakan merupakan masalah tidak jelas atau belum teridentifikasi. Peserta didik akan dihadapkan pada situasi yang membingungkan dan kompleks. Masalahnya tergambar pada awalnya wacana tidak sepenuhnya digambarkan (Fogarty, 1997)

Masalah digunakan untuk merangsang rasa ingin tahu, kemampuan analisis dan kemampuan pemecahan masalah. $P B L$ mempersiapkan peserta didik untuk dapat memecahkan masalah dengan sumber yang sesuai.

Dapat disimpulkan bahwa model $P B L$ merupakan model pembelajaran yang melibatkan peserta didik dalam memecahkan masalah nyata. Model Problem-based learning akan meningkatkan motivasi dan rasa ingin tahu. Model Problem-based learning juga menjadi tempat bagi peserta didik untuk mengembangkan cara berpikir kritis dan keterampilan berpikir yang lebih tinggi.

Model $P B L$ tepat digunakan pada mata pelajaran Biologi. Karakteristik Biologi dan $P B L$ memiliki keterkaitan, keduanya memiliki benang merah. Biologi merupakan ilmu pengetahuan yang terus berkembang dengan pesat. Peranan Biologi luas dalam berbagai aspek kehidupan.

Keberhasilan $P B L$ tergantung pada kemampuan dalam menyajikan masalah realistis yang akan membantu peserta didik mengembangkan kemampuan memecahkan masalah dan kemampuan untuk menjadi mandiri. Tujuan penting ketika menggunakan model ini adalah membawa dunia nyata ke dalam kelas untuk investigasi dan analisis. Salah satunya dengan penggunaan teknologi untuk mendukung PBL (Eggen \& Kauchak, 2012). Teknologi digunakan untuk menyajikan masalah dunia nyata agar lebih menarik. Salah satu jenis teknologi yaitu komik digital.

Komik merupakan bentuk kartun yang mengungkapkan karakter dan menerapkan suatu cerita dalam urutan yang erat hubungannya dengan gambar dan dirancang untuk memberikan hiburan kepada para pembaca. Komik dipilih sebagai suplemen karena memiliki manfaat sebagai berikut: (a) memperjelas materi; (b) menciptakan nilai rasa lebih dalam memahami materi; (c) membangkitkan perhatian dan minat peserta didik untuk membaca, sehingga dapat memperluas penguasaan kosa kata peserta didik; (d) peserta didik merasa senang karena komik dilengkapi gambar-gambar yang menarik; (e) membangkitkan rasa ingin tahu peserta didik; (f) memotivasi peserta didik untuk belajar; (g) dapat menciptakan pembelajaran yang efektif dan efisien. Selain itu jam pembelajaran yang terbatas menyebabkan pendidik kesulitan untuk mengajak peserta didik belajar di luar sekolah, sehingga diperlukan alat bantu berupa media pembelajaran yang dikemas secara virtual yang dapat memudahkan peserta didik dalam mengamati permasalahan terkait pencemaran lingkungan tanpa harus keluar kelas.

Berdasarkan uraian di atas maka perlu dilakukan penelitian mengenai bukti yang menggambarkan adanya pengaruh penerapan problem-based learning dengan suplemen komik pada materi pencemaran lingkungan. Ini dilakukan sebagai upaya meningkatkan kemampuan pemecahan masalah dan sikap peduli lingkungan biologi peserta didik di SMA Negeri 1 Sedayu.

\section{Metode Penelitian}

Jenis penelitian adalah penelitian eksperimen semu (quasi eksperiment) dengan dua kelompok 
sampel pada satu sekolah. Desain yang digunakan dalam penelitian ini adalah nonequivalent control group design (Louis, Lawrence, \& Keith, 2007), desain dapat dilihat pada Tabel 1.

Tabel I. Rancangan penelitian

\begin{tabular}{cccc}
\hline Kelas & Pretest & Perlakuan & Posttest \\
\hline A & $\mathrm{O}_{1}$ & $\mathrm{X}_{1}$ & $\mathrm{O}_{2}$ \\
B & $\mathrm{O}_{1}$ & $\mathrm{X}_{2}$ & $\mathrm{O}_{2}$ \\
C & $\mathrm{O}_{1}$ & $\mathrm{X}_{3}$ & $\mathrm{O}_{2}$ \\
D & $\mathrm{O}_{1}$ & $\mathrm{X}_{0}$ & $\mathrm{O}_{2}$ \\
\hline
\end{tabular}

Keterangan:

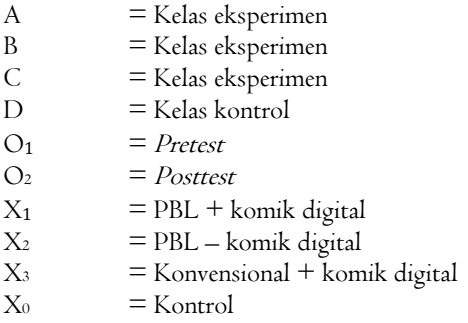

Penelitian dilakukan di SMAN 1 Sedayu yang berlokasi di Kemusuk, Argomulyo, Sedayu, Bantul, DIY. Penelitian dilaksanakan pada bulan 5 Maret sampai 5 Mei 2016.

Populasi dalam penelitian ini adalah seluruh peserta didik kelas X SMA N 1 Sedayu tahun ajaran 2015/2016 dengan jumlah 288 peserta didik, terdiri atas sembilan kelas yang masing-masing 32 peserta didik. Pemilihan kelas eksperimen dan kelas kontrol dilakukan berdasarkan saran dari pendidik biologi. Dari sembilan kelas yang ada dipilih empat kelas sebagai sampel, sehingga diperoleh kelas X MIA 1, X MIA 2, X MIA 4 sebagai kelas ekperimen dan X MIA 3 sebagai kelas kontrol.

Data yang dikumpulkan dalam penelitian yaitu data keterlaksanaan pembelajaran, kemampuan pemecahan masalah peserta didik, dan sikap peduli lingkungan peserta didik. Data pendukung berupa catatan lapangan. Sumber data yaitu peserta didik dan pendidik. Pengambilan data dibantu oleh tiga observer yang terdiri dari tiga mahasiswa program sarjana Pendidikan Biologi angkatan 2014. Data kemampuan pemecahan masalah diambil menggunakan tes kemampuan pemecahan masalah. Data sikap peduli lingkungan diambil menggunakan angket sikap peduli lingkungan.

\section{Hasil dan Pembahasan}

Hasil penelitian pengaruh penerapan model $P B L$ dengan suplemen komik digital materi pencemaran lingkungan terhadap kemampuan pemecahan masalah dan sikap peduli lingkungan. Berdasarkan hasil tes kemampuan pemecahan masalah yang dilakukan dengan pretest dan post-test dapat diketahui terdapat peningkatan persentase. Hasil kemampuan pemecahan masalah dapat dilihat pada Tabel 2.
Tabel 2. Hasil kemampuan pemecahan masalah peserta didik

\begin{tabular}{|c|c|c|c|c|c|}
\hline \multirow{2}{*}{ Data } & \multirow{2}{*}{ Kelas } & \multirow{2}{*}{$\mathrm{n}$} & \multicolumn{3}{|c|}{$\begin{array}{l}\text { Kemampuan pemecahan } \\
\text { masalah }\end{array}$} \\
\hline & & & $\begin{array}{c}\text { Nilai } \\
\text { terendah }\end{array}$ & $\begin{array}{c}\text { Nilai } \\
\text { tertinggi }\end{array}$ & rerata \\
\hline \multirow{4}{*}{ Pretest } & $\begin{array}{c}\text { Eksperimen } \\
1\end{array}$ & 32 & 30 & 70 & 57,65 \\
\hline & $\begin{array}{c}\text { Eksperimen } \\
2\end{array}$ & 32 & 30 & 70 & 56,25 \\
\hline & $\begin{array}{c}\text { Eksperimen } \\
3\end{array}$ & 32 & 35 & 70 & 56,56 \\
\hline & Kontrol & 32 & 30 & 70 & 55,31 \\
\hline \multirow{4}{*}{$\begin{array}{c}\text { Post- } \\
\text { test }\end{array}$} & $\begin{array}{c}\text { Eksperimen } \\
1\end{array}$ & 32 & 60 & 100 & 81,41 \\
\hline & $\begin{array}{c}\text { Eksperimen } \\
2\end{array}$ & 32 & 55 & 90 & 77,3 \\
\hline & $\begin{array}{c}\text { Eksperimen } \\
3\end{array}$ & 32 & 55 & 85 & 71,87 \\
\hline & Kontrol & 32 & 50 & 75 & 65,47 \\
\hline
\end{tabular}

Berdasarkan Tabel 2, diperoleh perbandingan rerata pretest dan post-test kemampuan pemecahan masalah peserta didik pada setiap kelas. Perbandingan rerata dapat dilihat pada Gambar 1.

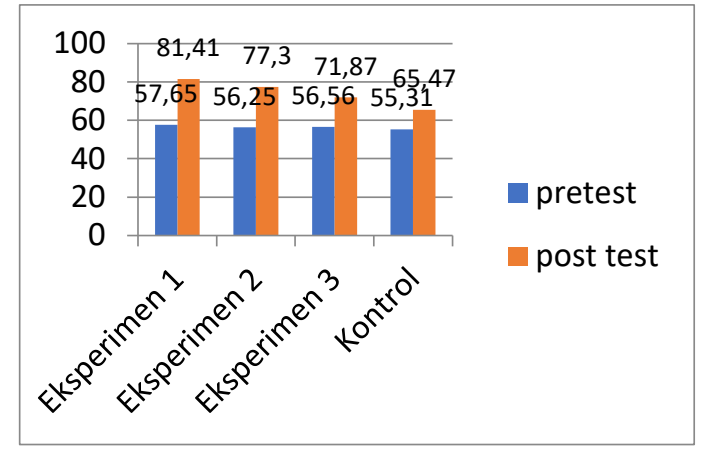

Gambar I. Rerata nilai kemampuan pemecaha masalah

Berdasarkan Gambar 1. dapat diketahui bahwa nilai awal kemampuan pemecahan masalah hampir sama yaitu antara 55 sampai 57 . Nilai rerata pretest digunakan untuk mengetahui kemampuan awal peserta didik tentang pemecahan masalah pada materi pencemaran lingkungan. Dari semua sampel kemampuan awal menunjukkan nilai yang relatif sama.

Tabel 3. Nilai indeks sensitivitas kemampuan pemecahan masalah

\begin{tabular}{cccccc}
\hline Bentuk & No & \multicolumn{4}{c}{ Nilai indeks sensitivitas } \\
\cline { 3 - 6 } soal & item & $\begin{array}{c}\text { Kls } \\
\text { eks 1 }\end{array}$ & $\begin{array}{c}\text { Kls } \\
\text { eks 2 }\end{array}$ & $\begin{array}{c}\text { Kls } \\
\text { eks 3 }\end{array}$ & $\begin{array}{c}\text { Kls } \\
\text { kontrol }\end{array}$ \\
\hline Uraian & 1 & 0,56 & 0,43 & 0,28 & 0,25 \\
& 2 & 0,50 & 0,50 & 0,37 & 0,28 \\
& 3 & 0,47 & 0,40 & 0,28 & 0,28 \\
& 4 & 0,53 & 0,37 & 0,34 & 0,19 \\
& 5 & 0,62 & 0,37 & 0,37 & 0,37 \\
& 6 & 0,47 & 0,37 & 0,28 & 0,31 \\
\hline
\end{tabular}

Nilai rerata setelah diberi perlakuan mengalami peningkatan, nilai rerata post-test yang tertinggi pada kelas eksperimen 1 yaitu 81,41. Kelas kontrol 
memiliki nilai rerata post-test terendah yaitu 65,47. Nilai indeks sensitivitas perlu diketahui untuk mengetahui pengaruh pembelajaran. Nilai indeks sensitivitas dapat dilihat pada Tabel 3.

Berdasarkan Tabel 3. dapat diketahui bahwa nilai indeks sensitivitas pada kelas eksperimen 1 menunjukkan angka tertinggi dibanding kelas eksperimen 2, kelas eksperimen 3, dan kelas kontrol. $\mathrm{Hal}$ tersebut menunjukkan bahwa skor tersebut efektif karena memiliki indeks sensitivitas 0,47 ke atas. Semakin tinggi nilai positif, dapat diartikan item lebih sensitif terhadap pengaruh pengajaran hasil belajar. Sebaliknya, item dengan nilai 0,0 dan nilai negatif berarti item tidak merefleksikan pengaruh pengajaran yang terencana (Sukardi, 2008).

Nilai sikap peduli lingkungan peserta didik diambil melalui angket. Angket yang dibuat terdiri dari tiga macam yaitu angket yang diisi oleh peserta didik, angket yang diisi oleh pendidik, dan angket yang diisi oleh observer. Hasil pengamatan terhadap sikap peduli lingkungan peserta didik kelas X MIA SMAN 1 Sedayu dapat dilihat pada Tabel 4.

Tabel 4. Hasil angket sikap peduli lingkungan peserta didik

\begin{tabular}{ccccc}
\hline \multirow{2}{*}{ Kelas } & $\mathbf{n}$ & \multicolumn{3}{c}{ Sikap peduli lingkungan } \\
\cline { 3 - 5 } & & $\begin{array}{c}\text { Nilai } \\
\text { terendah }\end{array}$ & $\begin{array}{c}\text { Nilai } \\
\text { tertinggi }\end{array}$ & Rerata \\
\hline Eksperimen 1 & 32 & 69,4 & 89,4 & 81,0 \\
Eksperimen 2 & 32 & 51,8 & 85,8 & 73,5 \\
Eksperimen 3 & 32 & 55,3 & 83,2 & 66,0 \\
Kontrol & 32 & 49,7 & 79,5 & 63,0 \\
\hline
\end{tabular}

Berdasarkan Tabel 4., perbandingan nilai sikap peduli lingkungan pada setiap kelas dapat dibuat diagram. Diagram tersebut dilihat pada Gambar 2.

Tabel 5. Hasil uji ANCOVA (post-test KPM)

\begin{tabular}{|c|c|c|c|c|c|c|}
\hline \multirow{2}{*}{$\begin{array}{c}(\mathrm{I}) \\
\text { model } \\
\text { pemb }\end{array}$} & \multirow{2}{*}{$\begin{array}{c}(\mathrm{J}) \\
\text { model } \\
\text { pemb }\end{array}$} & \multirow{2}{*}{$\begin{array}{l}\text { Perbedaan rerata } \\
\text { (I-J) }\end{array}$} & \multirow[t]{2}{*}{ Std. error } & \multirow[t]{2}{*}{ Sig. ${ }^{b}$} & \multicolumn{2}{|c|}{$95 \%$ confidence for difference } \\
\hline & & & & & Lower bound & Upper bound \\
\hline \multirow{3}{*}{ I } & 2 & 7.419 & 1.975 & .000 & 3.509 & 11.328 \\
\hline & 3 & $12.231^{\text {* }}$ & 1.975 & .000 & 8.322 & 16.141 \\
\hline & 4 & $17.188^{*}$ & 1.975 & .000 & 13.278 & 21.097 \\
\hline \multirow{3}{*}{2} & 1 & $-7.419^{* *}$ & 1.975 & .000 & -11.328 & -3.509 \\
\hline & 3 & $4.813^{\text {* }}$ & 1.975 & .016 & .903 & 8.722 \\
\hline & 4 & $9.769^{*}$ & 1.975 & .000 & 5.859 & 13.678 \\
\hline \multirow{3}{*}{3} & 1 & $-12.231^{*}$ & 1.975 & .000 & -16.141 & -8.322 \\
\hline & 2 & $-4.813^{* *}$ & 1.975 & .016 & -8.722 & -.903 \\
\hline & 4 & $4.956^{* *}$ & 1.975 & .013 & 1.047 & 8.866 \\
\hline \multirow{3}{*}{4} & 1 & $-17.188^{\text {\#x }}$ & 1.975 & .000 & -21.097 & -13.278 \\
\hline & 2 & $-9.769^{*}$ & 1.975 & .000 & -13.678 & -5.859 \\
\hline & 3 & $-4.956^{\text {* }}$ & 1.975 & .013 & -8.866 & -1.047 \\
\hline
\end{tabular}

Berdasarkan Tabel 5. dapat diketahui bahwa perbedaan rerata pada kelas eksperimen 1 dengan

kelas eksperimen 2 sebesar 7,419. Perbedaan rerata kelas ekperimen 1 dengan kelas eksperimen 3 sebesar

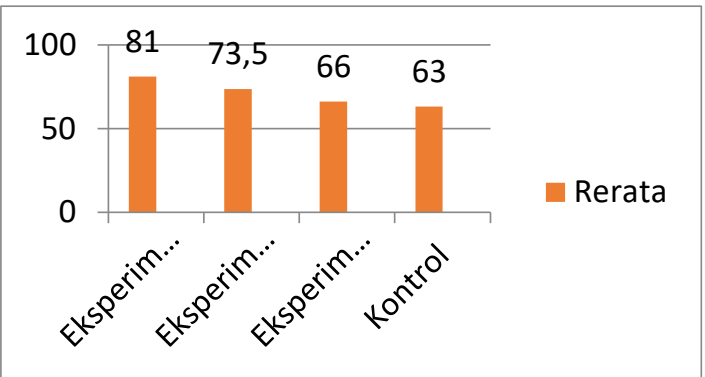

Gambar 2. Rerata sikap peduli lingkungan peserta didik

Berdasarkan Gambar 2. dapat diketahui bahwa nilai rerata sikap peduli lingkungan tertinggi ditunjukkan pada kelas eksperimen 1 yaitu 81 dengan perlakuan menggunakan $P B L$ disertai suplemen komik digital. Selanjutnya nilai rerata tertinggi kedua pada kelas eksperimen 2 yaitu 73,5 dengan perlakuan menggunakan $P B L$ tanpa suplemen komik digital. Nilai rerata tertinggi ketiga pada kelas eksperimen 3 yaitu 66 dengan perlakuan menggunakan pembelajaran konvensional disertai suplemen komik digital. Nilai rerata terendah pada kelas kontrol dengan nilai 63 dengan perlakuan menggunakan pembelajaran konvensional tanpa suplemen komik digital. Data angket sikap peduli lingkungan peserta didik selanjutnya dianalisis menggunakan uji Kruskal Wallis, hal tersebut dikarenakan data yang diperoleh bukan data berpasangan. Pengambilan data dilakukan satu kali yaitu pada akhir pertemuan.

Berdasarkan hasil uji prasyarat data nilai kemampuan pemecahan masalah dan sikap peduli lingkungan peserta didik data terdistribusi tidak normal dan varian datanya homogen. Selanjutnya data dianalisis dengan Analysis of Covariance (ANCOVA). Hasil uji ANCOVA dapat dilihat pada Tabel 5 . 
12,231. Perbedaan rerata kelas eksperimen 4 sebesar 17,188, dan seluruh perlakuan signifikan karena niai signifikansi $<0,05$.

Hasil angket sikap peduli lingkungan dianalisis dengan menggunakan Kruskal Wallis Test. Berdasarkan hasil uji Kruskal Wallis pada Tabel 4. dapat diketahui bahwa dalam hal sikap peduli lingkungan, peringkat rata-rata perlakuan dengan penerapan $P B L$ disertai komik digital lebih tinggi dibandingkan model lainnya dengan nilai mean rank berturut-turut sebesar 81,00; 73,50; 66,00; dan 63,00. Pembelajaran konvensional memiliki peringkat rata-rata terendah dibandingkan kelompok eksperimen dalam penelitian. Pada uji statistik tersebut juga diketahui bahwa diperoleh nilai signifikansi sebesar 0,000 yang berarti bahwa terdapat perbedaan yang signifikan antar perlakuan yang diberikan. Untuk mengetahui kelompok perlakuan atau model pembelajaran mana yang memberikan perbedaan dilakukan uji lanjut Least Significance Different (LSD).

Berdasarkan hasil uji lanjut LSD kemampuan pemecahan masalah disimpulkan bahwa kemampuan pemecahan masalah peserta didik antar kelas yaitu kelas eksperimen 1 ( $P B L$ disertai komik digital), kelas eksperimen 2 (PBL tanpa komik digital), kelas eksperimen 3 (konvensional disertai komik digital), dan kelas kontrol (konvensional tanpa komik digital) terdapat perbedaan yang signifikan. Perbedaan pengaruh perlakuan ditandai dengan nilai signifikansi yang menunjukkan nilai di bawah 0,05.

Berdasarkan hasil uji lanjut LSD sikap peduli lingkungan pada Tabel 5., disimpulkan bahwa sikap peduli lingkungan peserta didik antar kelas yaitu kelas eksperimen 1 (PBL disertai komik digital), kelas eksperimen 2 ( $P B L$ tanpa komik digital), dan kelas eksperimen 3 (konvensional disertai komik digital) terdapat perbedaan yang signifikan yang ditandai dengan nilai signifikansi kurang dari 0,05. Pada kelas eksperimen 3 dengan kelas kontrol tidak terdapat perbedaan yang ditunjukkan dengan nilai signifikansi lebih dari 0,05 , selain itu nilai rerata antara kelas eksperimen 3 dan kelas kontrol hampir sama, selisih 2,98.

Kemampuan awal peserta didik pada empat kelas yang digunakan untuk penelitian terkait kemampuan pemecahan masalah pada materi pencemaran lingkungan yang di uji dengan uji ANCOVA adalah setara, hal ini ditunjukkan oleh nilai signifikansi $>0,05$ yang bearrti tidak ada perbedaan.

Analisis mengenai data pretest kemampuan pemecahan masalah peserta didik diperlukan untuk mengetahui kesetaraan antar kelas. Hal ini dilakukan agar dapat dipastikan bahwa adanya perbedaan hasil post-test kemampuan pemecahan masalah disebabkan oleh perlakuan yang diberikan ketika penelitian.

Jumlah peserta didik dalam penelitian sebanyak 128 yang dikelompokkan dalam empat kelas. Kelas tersebut yaitu kelas dengan penerapan model $P B L$ disertai suplemen komik digital, penerapan $P B L$ tanpa komik digital, penerapan model konvensional disertai suplemen komik digital, dan penerapan model konvensional tanpa suplemen komik digital.

Hasil penelitian terkait kemampuan pemecahan masalah disampaikan sebagai berikut. Nilai rerata kemampuan pemecahan masalah setelah diberi perlakuan penerapan model $P B L$ dengan suplemen komik digital sebesar 85,1, rerata kemampuan pemecahan masalah setelah diberi perlakuan penerapan $P B L$ tanpa komik digital sebesar 77,6, rerata kemampuan pemecahan masalah setelah diberi perlakuan penerapan model konvensional dengan suplemen komik digital sebesar 73,5, dan rerata kemampuan pemecahan masalah setelah diberi perlakuan penerapan model konvensional tanpa suplemen komik digital sebesar 66,5.

Berdasarkan hasil uji statistik dapat diketahui bahwa antara kelas eksperimen 1 dengan kelas ekperimen 2 terdapat perbedaan yang nyata mengenai kemampuan pemecahan masalah. Hasil pada kelas ekperimen 1 lebih baik dari kelas ekperimen 2.

Di dalam kelas, peserta didik kelas eksperimen 1 terlihat aktif berdiskusi untuk memecahkan masalah dan mampu mempresentasikan hasil pemecahan masalah dengan baik. Peserta didik kelas eksperimen 1 juga aktif melakukan tanya jawab saat presentasi berlangsung. Hasil tersebut dapat membuktikan bahwa penerapan model $P B L$ dengan suplemen komik digital memberikan pengaruh yang lebih baik terhadap kemampuan pemecahan masalah dibanding penerapan $P B L$ tanpa suplemen komik digital. Alasan yang mendasari kelebihan $P B L$ dalam mencapai hasil kemampuan pemecahan masalah dapat dilihat dari sintaks $P B L$. Lima sintaks $P B L$ yang harus dilalui dalam menerapkan model $P B L$ antara lain: (1) berbasis pada masalah, (2) mengorganisasi peserta didik untuk belajar, (3) membimbing pengalaman individual/kelompok, (4) mengembangkan dan menyajikan produk, (5) menganalisis dan mengevaluasi proses pemecahan masalah (Arends, 2012).

Berdasarkan sintaks pembelajaran $P B L$ dapat dilihat bahwa peserta didik berperan lebih aktif untuk memecahkan masalah selama pembelajaran berlangsung. Pembelajaran yang berpusat pada pendidik akan mengurangi kesempatan peserta didik untuk mengasah kemampuan pemecahan masalah, 
dan kemampuan berpikir, selain itu komik digital memiliki peranan penting pada pembelajaran yaitu lebih menarik bagi peserta didik dan memberikan materi yang sesuai. Hal tersebut juga sesuai dengan pendapat Clark (dalam Albion \& Gibson, 1998) bahwa perubahan hasil belajar dipengaruhi metode pembelajaran yang tertanam dalam media. Kozma (dalam Albion \& Gibson, 1998) juga berpendapat bahwa perbedaan media yang mempengaruhi hasil tetapi kontribusi metode pembelajaran juga signifikan. Chapter pada komik digital sinkron dengan sintaks $P B L$ sehingga komik digital dapat meningkatkan hasil pembelajaran. Adapun sintaks PBL dapat dilihat pada Tabel 6.

Indikator berorientasi pada permasalahan sinkron dengan chapter pencamaran membawa bencana dan berubahnya kondisi sungai Gajah Wong. Indikator pengorganisasian peserta didik untuk meneliti sinkron dengan chapter sampah dan hujan. Indikator invetigasi sinkron dengan chapter dampak keberadaan manusia. Indikator pengembangan dan presentasi hasil karya sinkron dengan chapter potret sungai Gajah Wong. Indikator analisis dan evaluasi proses mengatasi masalah sinkron dengan chapter membuat kondisi sungai lebih baik. Sintaks $P B L$ sebagaimana disampaikan (Arends, 2012) ditampilkan dalam Tabel 6.

Tabel 6. Sintaks $P B L$

\begin{tabular}{|c|c|}
\hline Indikator & Tingkah laku pendidik \\
\hline $\begin{array}{l}\text { Orientasi peserta } \\
\text { didik pada } \\
\text { permasalahan }\end{array}$ & $\begin{array}{l}\text { Menjelaskan tujuan pembelajaran, } \\
\text { menjelaskan materi yang diperlukan, dan } \\
\text { memotivasi peserta didik untuk } \\
\text { memecahkan masalah }\end{array}$ \\
\hline $\begin{array}{l}\text { Pengorganisasian } \\
\text { peserta didik } \\
\text { untuk meneliti }\end{array}$ & $\begin{array}{l}\text { Membantu peserta didik mendefinisikan } \\
\text { dan mengorganisasikan tugas belajar yang } \\
\text { berhubungan denganh masalah yang } \\
\text { disediakan. }\end{array}$ \\
\hline Investigasi & $\begin{array}{l}\text { Membantu peserta didik untuk } \\
\text { mengumpulkan informasi yang sesuai, } \\
\text { melaksanakan percobaan untuk } \\
\text { mendapatkan penjelasan dan pemecahan } \\
\text { masalah }\end{array}$ \\
\hline $\begin{array}{l}\text { Pengembangan } \\
\text { dan presentasi } \\
\text { hasil karya }\end{array}$ & $\begin{array}{l}\text { Membantu peserta didik dalam } \\
\text { merencanakan dan menyiapkan produk } \\
\text { yang sesuai dengan laporan, dan } \\
\text { membantu pembagian tugas antar peserta } \\
\text { didik }\end{array}$ \\
\hline $\begin{array}{l}\text { Analisis dan } \\
\text { evaluasi proses } \\
\text { mengatasi } \\
\text { masalah }\end{array}$ & $\begin{array}{l}\text { Membantu peserta didik untuk } \\
\text { melakukan evaluasi terhadap penelitian } \\
\text { peserta didik dan proses yang digunakan }\end{array}$ \\
\hline
\end{tabular}

Peserta didik pada kelas eksperimen 2 terlihat aktif berdiskusi dalam kelompoknya untuk memecahkan masalah dan dapat mempresentasikan hasil pemecahan masalah dengan baik, akan tetapi saat tanya jawab peserta didik yang bertanya tidak sebanyak peserta didik yang bertanya pada kelas eksperimen 1. Hal tersebut dapat disebabkan oleh pengaruh tidak ada pemakaian komik digital pada kelas eksperimen 2. Komik digital memiliki peranan penting pada pembelajaran yaitu lebih menarik bagi peserta didik dan memberikan materi yang sesuai. Selain itu komik digital sangat meningkatkan keterlibatan peserta didik dalam pembelajaran dan mempersiapkan mereka untuk diskusi nyata dengan menyediakan konten dan penilaian sebelum pembelajaran (Bowen, 2012).

Peserta didik pada kelas eksperimen 3 terlihat antusias memperhatikan penjelasan pendidik dengan menggunakan komik digital dibanding kelas kontrol. Pada kelas kontrol peserta didik tampak tidak antusias mengikuti pelajaran, ketika pendidik menjelaskan peserta didik banyak yang tidak memperhatikan. Penerapan pembelajaran konvensional dengan suplemen komik digital memiliki beda signifikan dengan penerapan pembelajaran konvensional tanpa suplemen komik digital dikarenakan komik digital memiliki peranan penting pada pembelajaran yaitu lebih menarik bagi peserta didik dan memberikan materi yang sesuai.

Penerapan PBL dengan suplemen komik digital memiliki beda signifikan dengan penerapan pembelajaran konvensional dengan suplemen komik digital karena komik digital dengan $P B L$ sinkron, komik digital lebih menguatkan sintaks pembelajaran $P B L$ dengan sifatnya yang komplementer. Hal tersebut sesuai dengan pendapat Jonassen dan Hung (2008) bahwa menggunakan multimedia untuk meningkatkan $P B L$ didasarkan pada asumsi bahwa $P B L$ harus menempatkan dalam konteks otentik untuk membantu peserta didik mengkodekan spesifisitas informasi yang merupakan salah satu kondisi yang diperlukan untuk proses belajar terjadi.

Hasil analisis penerapan $P B L$ terhadap kemampuan pemecahan masalah bersesuaian dengan hasil penelitian yang dilakukan oleh Dewi, Sadia, dan Suma (2014), Kodariyati dan Astuti (2016). Secara garis besar hasil kedua penelitian tersebut menunjukkan bahwa penerapan $P B L$ dapat meningkatkan kemampuan pemecahan masalah peserta didik.

Hasil penelitian terkait sikap peduli lingkungan dapat disampaikan sebagai berikut. Nilai rerata sikap peduli lingkungan setelah diberi perlakuan penerapan model $P B L$ dengan suplemen komik digital sebesar 81, rerata sikap peduli lingkungan setelah diberi perlakuan penerapan $P B L$ tanpa komik digital sebesar 73,5, rerata sikap peduli lingkungan setelah diberi perlakuan penerapan model konvensional dengan suplemen komik digital sebesar 66, dan rerata sikap peduli lingkungan setelah diberi perlakuan penerapan model konvensional tanpa suplemen komik digital sebesar 63. 
Saat awal pembelajaran pada kelas eksperimen 1, kelas tampak kotor, sampah berserakan di bawah meja dan area belakang kelas, namun setiap pertemuan terdapat peningkatan dan akhirnya kelas eksperimen 1 sangat bersih. Selain itu peserta didik kelas eksperimen 1 aktif berdiskusi mengenai cara memecahkan masalah yang terjadi di lingkungan sekitar. Sangat berbeda jika dibandingkan dengan kelas kontrol, kelas dari pertemuan pertama sampai terakhir terlihat kotor, dan peserta didik tidak memperhatikan pendidik ketika pendidik mengajar.

$P B L$ sangat cocok digunakan pada materi pencemaran lingkungan, hal tersebut dikarenakan salah satu karakteristik $P B L$ adalah berangkat dari masalah yang nyata, terlebih dengan suplemen komik digital yang berjudul "Potret Sungai Gajah Wong" yang isi permasalahannya begitu dekat dengan siswa. Masalah pencemaran dewasa ini menjadi masalah yang krusial di Daerah Istimewa Yogyakarta (DIY). Sungai di DIY yang tercemar berat antara lain: Winongo, Code, Gajahwong, Bedog, Tambakbayan, Oyo, Kuning, Konteng, Belik dan Bulus. Selain itu di dekat SMA N 1 Sedayu juga terdapat Sungai Progo yang mengalami eksploitasi pasir menggunakan alat berat dan dapat menyebabkan rusaknya ekosistem sungai.

Masalah tersebut membuat Pemerintah mengeluarkan program M3K yaitu Mundur, Munggah, Madhep kali yang diadakan di wilayah sungai Code, tujuannya adalah untuk memelihara bantaran sungai dan aliran sungai tetap terjaga (Dirjen SDA, 2015). Program lain berupa kegiatan Nandur Banyu Panguripan, Ngabuk Paseduluran, yang dimaksud adalah meleburkan aktivitas budaya dengan aktivitas pelestarian lingkungan (PPID, 2015). Hal tersebut bertujuan untuk memberikan informasi kepada masyarakat bahwa kebudayaan dapat digunakan untuk kesejahteraan rakyat.

Sikap peduli lingkungan peserta didik semakin meningkat setelah mempelajari konsep perusakan dan pencemaran lingkungan melalui model $P B L$, terlebih dengan suplemen komik digital. Sintaks pada $P B L$ dapat menumbuhkan rasa ingin tahu peserta didik tentang lingkungan sekitarnya. Masalah yang dimunculkan pada awal proses pembelajaran $P B L$ dapat membuka wawasan peserta didik terhadap alam sekitar karena masalah yang disajikan ada di sekitar peserta didik. Oleh karena itu peserta didik lebih tertarik dan merasa belajar bukan untuk mengetahui teori semata tetapi peserta didik berperan sebagai pencari solusi dari masalah yang terjadi.

Dengan berlatih memecahkan masalah, peserta didik akan bertambah pengalamannya tentang menangani pencemaran lingkungan. Dengan demikian wawasan peserta didik untuk menjaga lingkungan bertambah, berarti sikap peduli lingkungan peserta didik meningkat. Oleh sebab itu penerapan PBL dengan suplemen komik digital memberikan pengaruh yang tinggi pada sikap peduli lingkungan peserta didik.

Suplemen yang diberikan pada perlakuan adalah komik digital yang berjudul "Potret sungai Gajah Wong”. Komik digital ini merupakan karya Dini Marselia, mahasiswa Universitas Negeri Yogyakarta Jurusan Pendidikan Biologi. Komik digital ini digunakan dengan software aplikasi adobe flash player yang dapat diputar pada komputer atau handphone. Komik digital "Potret sungai Gajah Wong" merupakan materi dari pencemaran lingkungan yang diajarkan di kelas X SMA semester 2. Komik digital ini telah diuji terbatas pada 10 peserta didik SMA Muhammadiyah. Hasil uji coba menunjukkan bahwa komik digital memberi pengaruh yang signifikan meningkatkan sikap peduli lingkungan peserta didik.

Komik digital "Potret sungai Gajah Wong" terdiri dari tujuh topik yaitu: (1) sampah dan hujan, (2) sungai sumber kehidupan, (3) dampak keberadaan manusia, (4) Pencemaran membawa bencana, (5) potret sungai gajah Wong, (6) berubahnya kondisi Gajah Wong, (7) membuat kondisi sungai lebih baik. Isi materi pada pada komik digital sesuai dengan indikator pada materi pencemaran lingkungan yaitu (1) peserta didik mampu mengidentifikasi jenis-jenis limbah, (2) peserta didik mampu mengidentifikasi kerusakan pada sungai, (3) peserta didik mampu menjelaskan baku mutu yang berkaitan dengan pencemaran air di sungai, (4) peserta didik mampu menjelaskan ciri sungai yang tercemar, (5) peserta didik mampu mendeskripsikan pelestarian lingkungan, (6) peserta didik mampu membuat usulan pelestarian lingkungan, (7) peserta didik mampu membuat produk daur ulang limbah.

Pemilihan komik digital ini untuk digunakan sebagai suplemen dalam penelitian berdasarkan kelebihannya yang sesuai dengan pendapat Tatalovic (2009) bahwa manfaat komik digital sebagai media pembelajaran adalah: memperjelas materi; menciptakan nilai rasa lebih dalam memahami materi; membangkitkan perhatian dan minat peserta didik untuk membaca, sehingga dapat memperluas penguasaan kosa kata peserta didik; peserta didik merasa senang karena komik digital dilengkapi gambar-gambar yang menarik; membangkitkan rasa ingin tahu peserta didik; memotivasi peserta didik untuk belajar; dapat menciptakan pembelajaran yang efektif dan efisien. 


\section{Simpulan}

Penerapan $P B L$ dengan suplemen komik digital secara signifikan berpengaruh positif terhadap kemampuan pemecahan masalah dan sikap peduli lingkungan dibanding perlakuan lainnya. Penerapan $P B L$ dengan suplemen komik digital memiliki beda signifikan dengan penerapan $P B L$ tanpa suplemen komik digital karena komik digital memiliki peranan pada pembelajaran yaitu lebih menarik bagi peserta didik dan memberikan materi yang sesuai. Penerapan $P B L$ dengan suplemen komik digital memiliki beda signifikan dengan penerapan pembelajaran konvensional dengan suplemen komik digital karena chapter dari komik digital dengan sintaks $P B L$ sinkron, komik digital lebih menguatkan sintaks pembelajaran PBL dengan sifatnya yang komplementer.

\section{Daftar Pustaka}

Albion, P. R., \& Gibson, I. (1998). Designing multimedia materials using a problem-based learning design. In In Proceedings of the I5th Annual Conference of the Australasian Society for Computers in Learning in Tertiary Education (hal. 39-47). ASCILITE.

Arends, R. (2012). Learning to teach (9th ed.). New York: McGraw-Hill.

Bowen, J. A. (2012). Teaching naked: how moving technology out of your college classroom will improve student learning. San Francisco: Jossey-Bass.

Dewi, P. S. U., Sadia, I. W., \& Suma, K. (2014). Pengaruh model problem based learning terhadap kemampuan pemecahan masalah fisika melalui pengendalian bakat numerik siswa SMP. Jurnal Pendidikan IPA Indonesia, 4(I).

Eggen, P. D., \& Kauchak, D. P. (2012). Strategies and models for teachers: teaching content and thinking skills (6th ed.). Boston: Pearson.
Fogarty, R. (1997). Problem-based learning and other curriculum models for the multiple intelligences classroom. California: SAGE Publications.

Harsanto, R. (2011). Pengelolaan kelas yang dinamis. Yogyakarta: KANISIUS.

Jonassen, D. H., \& Hung, W. (2008). All problems are not equal: Implications for problembased learning. Interdisciplinary Journal of Problem-Based Learning, 2(2). https://doi.org/10.7771/1541-5015.1080

Kemendikbud. (2013). Materi pelatihan kurikulum 2013. Jakarta.

Kodariyati, L., \& Astuti, B. (2016). Pengaruh model PBL terhadap kemampuan komunikasi dan pemecahan masalah matematika peserta didik kelas v SD. Jurnal Prima Edukasia, 41) 93-106. http://dx.doi.org/10.21831/jpe.v4i1.7713

Louis, C., Lawrence, M., \& Keith, M. (2007). Research methods in education (6th ed.). New York: Routledge.

PPID. (2015). Napak tilas petilasan Kulon Progo. Diambil 6 April 2017, dari http://ppid.kulonprogokab.go.id/article568-napak-tilas-petilasan-kulon-progo.html

SDA, D. (2015). Kondisi muka air sungai. Jakarta.

Sukardi, H. M. (2008). Evaluasi pendidikan prinsip dan operasionalnya. Jakarta: Bumi Aksara.

Tan, O. S. (2003). Problem-based learning innovation: using problems to power learning in the 2Ist century. Boston: Cengage Learning.

Tatalovic, M. (2009). Science comics as tools for science education and communication: a brief, exploratory study. Journal of Science Communication, 8(4), 1-17.

Trianto, M. P. (2009). Mendesain model pembelajaran inovatif-progresif. Jakarta: Kencana. 